\title{
ANALISIS PENGARUH KOMUNIKASI E-WOM TERHADAP BRAND EQUITY DAN PURCHASE INTENTION PADA LUXURY FASHION ITEM E- COMMERCE BANANANINA DI MEDIA SOSIAL INSTAGRAM
}

\author{
Hanako Fatimah Pertiwi, Effy Zalfiana Rusfian \\ Universitas Indonesia (UI) Jakarta, Indonesia \\ Email: hanako.fatimah@gmail.com,effy_rusf@yahoo.co.id
}

\begin{abstract}
Abstrak
Maraknya pertumbuhan e-commerce dan pengguna media sosial di Indonesia telah menggeser penjualan barang fashion dari offline ke online. Perilaku konsumen masyarakat Asia termasuk Indonesia kini meminati barang mewah dengan membeli secara online. Dahulu, strategi pemasaran hanya dititik beratkan pada konten yang dibuat perusahaan saja, namun sekarang komunikasi media sosial pemasaran dapat dibuat melalui e-WOM yang dibentuk baik oleh perusahaan maupun oleh pengguna dengan cara membagikan konten di Instagram untuk menciptakan ekuitas merek dan minat beli konsumen. Banananina merupakan e-commerce asal Indonesia yang memanfaatkan Instagram sebagai media untuk memasarkan produknya. Penelitian ini bertujuan untuk menganalisis pengaruh komunikasi media sosial Instagram, baik dengan konten yang dibuat oleh pengguna Instagram maupun konten Instagram yang dibuat perusahaan Banananina yang membentuk e-WOM terhadap minat beli konsumen pada produk Banananina. Data hasil penelitian diolah dengan analisis Structural Equation Modeling (SEM) dengan menggunakan analisis Partial Least Square (PLS). Hasil yang ditemukan pada penelitian ini adalah bahwa usergenerated content dan firm-generated content memiliki pengaruh signifikan terhadap e-WOM. E-WOM juga secara signifikan memengaruhi minat beli dan ekuitas merek serta E-WOM yang dimediasi oleh ekuitas merek memiliki pengaruh signifikan terhadap minat beli konsumen pada merek Banananina di media sosial Instagram.
\end{abstract}

Kata Kunci: komunikasi media sosial; user-generated content; firm-generated content; E-WOM; minat beli; ekuitas merek

\section{Abstract}

The rapid growth of e-commerce and social media users in Indonesia has shifted sales of fashion goods from offline to online. Asian consumers, including Indonesia, are now interested in luxury items by buying online. Marketing strategies are usually only focused on content created by the company. But now, social media marketing communications can be made through e-WOM, which is formed by both companies and users by sharing content on Instagram to create brand equity and consumer buying interest. Banananina is an e-commerce from Indonesia that uses Instagram as a medium to market its products. This study aims to analyze the influence of Instagram social media communication, both with content created by Instagram

$\begin{array}{ll}\text { How to cite: } & \text { Pertiwi, Hanako Fatimah dan Effy Zalfiana Rusfian (2021) Analisis Pengaruh Komunikasi E-WOM } \\ & \text { terhadap Brand Equity dan Purchase Intention pada Luxury Fashion Brand Banananina di Media } \\ & \text { Sosial Instagram. Syntax Literate: Jurnal Ilmiah Indonesia. } 6(7) . \text { http://dx.doi.org/10.36418/syntax- } \\ & \text { literate.v6i7.3559 } \\ & 2548-1398 \\ \text { E-ISSN: } & \text { Ridwan Institute }\end{array}$


users and Instagram content created by the Banananina company which can form eWOM on consumer buying interest in Banananina products. The research data were processed using Structural Equation Modeling (SEM) analysis using Partial Least Square (PLS) analysis. The results found in this study are that user-generated content and firm-generated content have a significant effect on e-WOM. E-WOM also significantly affects buying interest and brand equity and E-WOM which is mediated by brand equity has a significant influence on consumer purchase interest in the Banananina brand on Instagram social media.

Keywords: social media communication; user-generated content; firm-generated content; E-WOM; purchase intention; brand equity

\section{Pendahuluan}

Persebaran internet yang cepat telah menimbulkan pertumbuhan pasar $e$ commerce yang luas (Abumalloh, Ibrahim, Nilashi, \& Abu-Ulbeh, 2017). Berdasarkan (Pusparisa, 2019), terdapat beberapa sektor barang yang paling sering dibeli oleh konsumen secara online (e-commerce). Data dari laporan Nielsen dalam Global Consumers Claimed Purchasing barang yang paling sering dibeli oleh konsumen dari yang tertinggi adalah sektor fashion. Tren fashion saat ini adalah luxury fashion brands yang berasal dari Benua Eropa dan Amerika. Konsumen terbesar dari barang fashion bermerek tersebut berasal dari Benua Asia. Konsumen Indonesia yang dulunya berburu untuk membeli barang bermerek bekas, kini mampu membeli barang bermerek baru. Permintaan tersebut terus naik dari tahun ke tahun terutama pada industri e-commerce (Kala \& Chaubey, 2018). Fenomena peningkatan belanja online pada luxury item di Indonesia pada bidang fashion menjadi latar belakang dari penulisan ini.

E-commerce dapat menggunakan media sosial sebagai salah satu sarana untuk melakukan pemasaran. Saat ini, posting di Blog, Tweet, atau video YouTube dapat diproduksi dan dilihat oleh jutaan orang secara virtual dan gratis. Pengiklan tidak perlu membayar dalam jumlah yang besar kepada penerbit atau distributor untuk memberikan iklan kepada calon konsumen karena mereka dapat membuat konten menarik sendiri yang akan ditonton orang (Zarella, 2010). Berdasarkan data riset Curponation, Indonesia menjadi negara terbesar keempat di dunia yang menggunakan sosial media Facebook dan Instagram (Nancy, 2019). Baik Instagram maupun Facebook dikenal media sosial yang membantu pebisnis untuk memasarkan produknya. Instagram dikenal dengan aplikasi berbagi foto dengan menggunakan filter untuk membuat foto dari kamera telepon genggam agar terlihat lebih profesional yang kemudian diunggah dan dibagikan (Kotler \& Keller, 2016).

Menurut (Sagala \& Rachmawati, 2016) pada penelitiannya yang berjudul "Instagram Content Towards Customers' Purchase Intention for Start-up Culinary Company”, Instagram sebagai salah satu sumber komersial yang akan menjadi salah satu solusi bagi pelanggan untuk mencari informasi yang mereka butuhkan. Konten yang baik di Instagram akan memberikan kesan yang baik kepada pelanggan. Menurut (Kotler \& Armstrong, 2012) terkadang keputusan pembelian dibuat bukan dari pelanggan itu, tapi karena adanya rekomendasi dari teman, ulasan online, atau orang yang menjual produk 
tersebut. Konten yang ada di Instagram cocok untuk pelanggan yang menggunakan jaringan sosial sebagai referensi untuk melakukan pembelian. Sagala dan Rachmawati menggunakan variabel konten di Instagram, seperti biodata perusahaan atau $e$-commerce secara visual, produk secara visual, endorsement, keterangan pada foto, hashtag, dan repost atau konten-konten yang dapat memberikan pengaruh pada keputusan pembelian. Word of mouth dan buzz marketing serta jaringan sosial online memengaruhi perilaku pembelian pelanggan, adanya Instagram memberikan peluang sebagai media untuk melakukan pemasaran produk secara global.

Word Of Mouth (WOM) dikenal sebagai sumber yang paling berpengaruh dalam transmisi informasi. Adanya teknologi membuat munculnya jaringan sosial melalui web yang mengubah bagaimana informasi yang disampaikan tidak hanya terbatas pada batas kontak sosial saja, hal ini disebut dengan e-WOM (Jalilvand \& Samiei, 2012). Menurut (Jha, 2019), Online review atau electronic word of mouth menjadi alat yang penting bagi pembeli online sebagai sumber infomasi produk dan karakteristik evaluasi sebelum membuat keputusan pembelian.

E-WOM bisa terbentuk karena adanya pengaruh dari social media communication. Menurut (Schivinski \& Dabrowski, 2015), terdapat dua jenis social media communication, yaitu yang dapat dikendalikan oleh perusahaan (firm-created content) dan yang kedua adalah independen dan tidak bisa dikendalikan oleh perusahaan, yaitu yang dibuat oleh pengguna (user-generated content). Pada penelitian yang dilakukan oleh (Poturak \& Softic, 2019) yang berjudul "Influence of Social Media Content on Consumer Purchase Intention: Mediation Effect of Brand Equity” melihat pengaruh firm created content dan user-generated content pengaruh e-WOM dan brand equity untuk mengukur pengaruhnya terhadap minat beli pelanggan. Hasil menunjukkan bahwa orang memiliki minat untuk membeli merek dalam negeri melalui adanya efek ekuitas merek yang terkait erat dengan e-WOM. Analisis menunjukkan bahwa firm-created dan user-generated, keduanya memiliki dampak yang signifikan pada penciptaan e-WOM dan juga brand equity.

Selain dipengaruhi oleh e-WOM, minat beli juga dapat dipengaruhi oleh adanya brand equity. Menurut (Aaker, 1991), brand equity sering didefinisikan sebagai sekumpulan aset merek dan liabilitas yang berhubungan pada sebuah merek, namanya dan simbol yang menambah atau mengurangi nilai produk atau jasa di sebuah perusahaan atau perusahaan pelanggan. Menurut (Zailskaite-Jakste \& Kuvykaitè, 2013), komunikasi di media sosial dapat membangun ekuitas merek (brand equity). Brand equity dapat memengaruhi keputusan pembelian, hal ini seperti yang diteliti oleh (Soewandi, 2015) bahwa terdapat hubungan positif antara brand equity terhadap minat pembeli di $e$ commerce yang pada akhirnya memengaruhi minat beli. Seperti pada jurnal penelitian yang dilakukan oleh (Poturak \& Softic, 2019) dengan judul "Influence of Social Media Content on Consumer Purchase Intention: Mediation Effect of Brand Equity" melihat bahwa komunikasi dari perusahaan maupun user di sosial media memengaruhi brand equity dan menciptakan efek mediasi antara e-WOM dan purchase intention. Hal ini 
menunjukkan bahwa terdapat hubungan pengaruh antara e-WOM, brand equity, dan purchase intention.

Fenomena peningkatan belanja online pada luxury item yang semakin meningkat terutama pada bidang fashion menjadi latar belakang penulisan ini. Peneliti ingin menganalisis seberapa kuat pengaruh dari adanya konten yang dibuat oleh perusahaan (firm-generated content) yang menjual luxury items dan pengguna (user-generated content) di media sosial Instagram yang membentuk e-WOM terhadap brand equity dan purchase intention. Selain itu, peneliti ingin meninjau dan menganalisis pengaruh brand equity terhadap purchase intention dan brand equity sebagai mediator dari e-WOM terhadap purchase intention. Pada penelitian ini berbeda dengan objek pada penelitian lain, objek yang dipilih adalah Banananina sebagai salah satu e-commerce di bidang luxury fashion items memanfaatkan media sosial yaitu Instagram sebagai sarana komunikasi terhadap calon konsumen dengan akun yang bernama @ shopatbanananina.

Memunculkan purchase intention dan brand equity yang kuat diperlukan komunikasi media sosial yang baik. Komunikasi media sosial yang baik tersebut diciptakan tidak hanya oleh perusahaan saja, tetapi juga bisa diciptakan oleh konsumen. Atas dasar tersebut maka diperlukan pengujian penelitian dan penelitian ini diberi judul "Analisis Pengaruh Komunikasi E-WOM yang dibuat oleh Pengguna dan Perusahaan terhadap Brand Equity dan Purchase Intention (Studi pada E-commerce di Instagram Banananina)". Sedangkan hipotesis penelitian ini diantaranya adalah 1) Terdapat pengaruh positif antara komunikasi yang dibuat oleh pengguna (user-generated content) dengan e-WOM pada brand Banananina di media sosial Instagram; 2) Terdapat pengaruh positif antara komunikasi yang dibuat oleh perusahaan (firm-generated content) Banananina dengan e-WOM pada brand Banananina di media sosial Instagram; 3) Terdapat pengaruh positif antara e-WOM dengan purchase intention konsumen pada brand Banananina di media sosial Instagram; 4) Terdapat pengaruh positif antara e-WOM dengan brand equity pada brand Banananina di media sosial Instagram; 5) Terdapat pengaruh positif antara brand equity dengan purchase intention pada brand Banananina di media sosial Instagram; 6) Terdapat pengaruh positif antara e-WOM dengan purchase intention konsumen melalui brand equity sebagai variabel intervening pada brand Banananina di media sosial Instagram.

Penelitian ini bertujuan untuk menganalisis pengaruh komunikasi media sosial Instagram, baik dengan konten yang dibuat oleh pengguna Instagram maupun konten Instagram yang dibuat perusahaan Banananina yang membentuk e-WOM terhadap minat beli konsumen pada produk Banananina.

\section{Metode Penelitian}

Metode dalam melakukan pengumpulan data pada penelitian ini adalah melalui kuesioner dengan populasi responden berupa seluruh pengguna Instagram dengan teknik pengambilan sampel non probability sampling dengan teknik purposive sampling yang menggunakan karakteristik tertentu dari populasi tertentu. Kriteria responden penelitian yang digunakan sebagai sampel yaitu responden yang merupakan pengguna Instagram di 
seluruh Indonesia yang mengetahui Instagram Banananina serta belum pernah melakukan pembelian produk apapun pada merek Banananina. Kuesioner dibuat dengan menggunakan Google Form dan disebarkan melalui media sosial kepada responden.

Pendekatan penelitian yang digunakan dalam penelitian ini adalah kuantitatif. Penelitian kuantitatif adalah pendekatan penelitian yang bersifat objektif mencakup pengumpulan dan analisis data kuantitatif serta menggunakan metode pengujian statistik (Hermawan \& Yusran, 2017). Data primer penelitian ini diperoleh dari hasil pengisian kuesioner dengan isian pernyataan-pernyataan dengan penilaian 6 poin skala Likert terhadap pengguna Instagram. Setelah hasil data diperoleh, data dianalisis untuk menguji hipotesis dengan menggunakan analisis PLS (Partial Least Square) yang merupakan salah satu metode statistika SEM (Structural Equation Modeling). Sedangkan, data sekunder diperoleh dengan cara mencari sumber-sumber ilmiah berupa jurnal, buku, dan artikel yang relevan dengan penelitian.

Berdasarkan penelitian ini, jumlah sampel responden yang mengisi kuesioner melalui google form harus memenuhi persyaratan jumlah minimal penelitian SEM, yaitu 5-10 kali jumlah indikator. Indikator pada penelitian ini berjumlah sebesar 31, sehingga sampel yang akan diambil adalah minimal 5 x 31 indikator = 155 sampel (Haryono, 2017). Pada penelitian ini, sampel yang diperoleh dari pengisian kuesioner adalah sebanyak 162 sampel sehingga telah memenuhi persyaratan untuk menggunakan SEM.

\section{Hasil dan Pembahasan}

Hasil penelitian ini dilakukan dengan analisis statistik deskriptif dan menguji pengaruh antar variabel dengan SmartPLS. Ditemukan bahwa mayoritas responden merupakan perempuan, yaitu sebanyak 124 orang dari 162 responden. Hal ini sesuai dengan target konsumen dari Banananina, yaitu perempuan. Sedangkan pada kategori usia, kebanyakan responden adalah berusia 23-28 tahun, hal ini sama dengan target pasar dari e-commerce Banananina, yaitu perempuan berusia 24-45 tahun. Sedangkan pada pekerjaan, mayoritas responden berprofesi sebagai pegawai swasta dan mayoritas tingkat pendidikan responden adalah Sarjana (S1). Pada tingkat pengeluaran per bulan, mayoritas responden memiliki Rp 2.000.000 - 2.999.999 dan Rp 3.000.000 - 4.999.999. Hal ini menunjukkan bahwa responden merupakan kelompok menengah dan menengah ke atas berdasarkan pengkategorian dari Boston Consulting Group.

Hasil pada penelitian dilakukan dengan menguji pengaruh antar variabel yang diteliti. Pengujian hipotesis dilakukan dengan menggunakan analisis SmartPLS yang menunjukkan diagram alur sehingga dapat dibandingkan nilai t hitung dengan t tabel. Apabila nilai dari $t$ hitung $>\mathrm{t}$ tabel, maka hubungan yang diperoleh antar variabel adalah signifikan. Berikut merupakan gambar yang menunjukkan hasil dari pengujian hipotesis. 


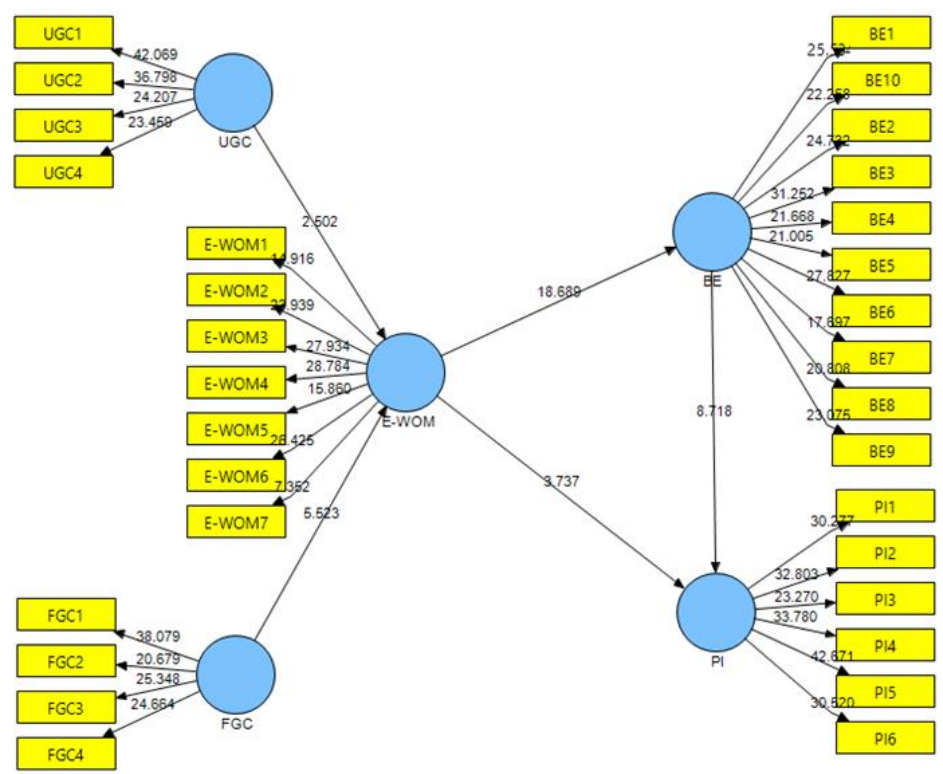

\section{Gambar 1}

\section{Diagram Jalur Hasil Pengujian Hipotesis}

Signifikan pada level 5\% dengan nilai t tabel pada level 5\% adalah sebesar 1,64. Tabel di bawah ini merupakan ringkasan hasil dari pengujian hipotesis dari penelitian.

Tabel 1

Hasil Pengujian Hipotesis

\begin{tabular}{ccccc}
\hline No & Pengaruh & Koe. Jalur & t hitung & Hasil \\
\hline $\mathbf{1 .}$ & UGC $\rightarrow$ E-WOM & 0,2510 & 2,5024 & Terima H1 \\
\hline $\mathbf{2 .}$ & FGC $\rightarrow$ E-WOM & 0,4812 & 5,5231 & Terima H2 \\
\hline $\mathbf{3 ,}$ & E-WOM $\rightarrow$ PI & 0,2784 & 3,7373 & Terima H3 \\
\hline $\mathbf{4 .}$ & E-WOM $\rightarrow$ BE & 0,7169 & 18,6887 & Terima H4 \\
\hline $\mathbf{5 .}$ & BE $\rightarrow$ PI & 0,5939 & 8,7182 & Terima H5 \\
\hline 6. & E-WOM $\rightarrow$ BE $\rightarrow$ PI & 0,4258 & 6,5639 & Terima H6 \\
\hline
\end{tabular}

Sumber: Hasil Olahan Data Penelitian, 2020

Berdasarkan tabel 1, maka dapat diperoleh hasil ringkasan dari penelitian yang telah menguji hipotesis. Dari hasil yang diperoleh dapat dilihat bahwa semua hipotesis yang diuji memiliki hasil positif yang signifikan. 


\section{Tabel 2}

Ringkasan Hasil Pengujian Hipotesis

$\begin{array}{cl}\begin{array}{c}\text { Ringkasan } \\ \text { Hasil }\end{array} \begin{array}{l}\text { Komunikasi yang dibuat oleh pengguna (user-generated } \\ \text { Pengujian } \\ \text { Hipotesis }\end{array} & \begin{array}{l}\text { content) berpengaruh signifikan terhadap e-WOM pada brand } \\ \text { Banananina di media sosial Instagram }\end{array} \\ & \begin{array}{l}\text { Komunikasi yang dibuat oleh perusahaan (firm-generated } \\ \text { content) Banananina berpengaruh signifikan terhadap terhadap } \\ \text { e-WOM pada brand Banananina di media sosial Instagram. }\end{array} \\ & \begin{array}{l}\text { E-WOM berpengaruh signifikan terhadap purchase intention } \\ \text { konsumen pada brand } \text { Banananina di media sosial Instagram. }\end{array} \\ & \begin{array}{l}\text { E-WOM berpengaruh signifikan terhadap brand equity pada } \\ \text { brand } \text { Banananina di media sosial Instagram. }\end{array} \\ & \begin{array}{l}\text { Brand equity berpengaruh signifikan terhadap purchase } \\ \text { intention pada brand Banananina di media sosial Instagram. }\end{array} \\ & \begin{array}{l}\text { E-WOM berpengaruh signifikan terhadap purchase intention } \\ \text { konsumen melalui brand equity sebagai variabel intervening } \\ \text { pada brand } \text { Banananina di media sosial Instagram. }\end{array}\end{array}$

Sumber: Hasil Olahan Data Penelitian, 2020

1. Terdapat Pengaruh yang Signifikan antara User-Generated Content terhadap eWOM

Hipotesis 1 menyatakan bahwa terdapat pengaruh positif antara komunikasi yang dibuat oleh pengguna (user-generated content) dengan e-WOM pada brand Banananina di media sosial Instagram.

Berdasarkan hasil pengujian hipotesis, nilai t-statistik pada pengaruh komunikasi yang dibuat oleh pengguna (user-generated content) Instagram terhadap e-WOM pada brand Banananina di media sosial Instagram adalah sebesar 2,5024. Hal ini menunjukkan bahwa t hitung $>\mathrm{t}$ tabel atau 2,5024 $>1,64$ sehingga hipotesis penelitian diterima. Hasil ini memberi arti bahwa terdapat pengaruh positif yang signifikan pada komunikasi yang dibuat oleh pengguna (user-generated content) terhadap e-WOM pada brand Banananina dengan pengaruh sebesar 0,2510 sehingga semakin meningkat komunikasi yang dibuat pengguna (user-generated content) di Instagram mengenai brand Banananina maka akan meningkatkan e-WOM pada brand Banananina di media sosial Instagram juga.

Hasil penelitian ini mendukung penelitian yang telah dilakukan oleh (Poturak \& Softic, 2019) yang menunjukkan bahwa user-generated content ditemukan memiliki pengaruh positif yang signifikan terhadape-WOM pada produk domestik tertentu. Jika dilihat dari analisis deskriptif pada variabel penelitian, variabel user-generated content termasuk dalam kategori agak tinggi dan tinggi. Setiap pernyataan pada variabel dari user-generated content memiliki mayoritas jawaban setuju dan sangat setuju sehingga hal tersebut menunjukkan bahwa komunikasi yang dibuat oleh pengguna Instagram untuk memperkuat e-WOM pada brand Banananina di media sosial Instagram. Hal ini diperkuat dengan hasil penelitian yang dilakukan yaitu thitung > t tabel atau 2,5024 > 1,64 yang menunjukkan adanya pengaruh yang signifikan. 
User-generated content merupakan informasi yang dibuat oleh orang atau pengguna di media sosial untuk dibagikan ke orang lain. UGC dalam penelitian ini diciptakan pengguna di media sosial Instagram berdasarkan pengalamannya dengan melakukan sharing melalui foto, repost, hashtag, story, dan review produk Banananina. Konten-konten tersebut dapat membentuk e-WOM sehingga dapat memengaruhi persepsi konsumen terhadap produk. User-generated content mendapatkan hasil yang signifikan yang didominasi oleh jawaban setuju dan sangat setuju sehingga pengguna Instagram menjadi penting dalam memberikan pengaruh terbentuknya e-WOM. Komponen seperti kepuasan responden dan daya tarik konten yang dibuat pengguna lain mengenai brand Banananina agak tinggi. Sementara itu ekspektasi dan juga kinerja atau performance konten dari yang dihasilkan oleh pengguna lain di media sosial Instagram mengenai brand Banananina dibandingkan brand kompetitor memiliki kategori yang tinggi.

2. Terdapat Pengaruh yang Signifikan antara Firm-generated Content terhadap e-WOM

Hipotesis 2 menyatakan bahwa terdapat pengaruh positif antara komunikasi yang dibuat oleh perusahaan (firm-generated content) Banananina dengan e-WOM pada brand Banananina di media sosial Instagram.

Berdasarkan hasil pengujian hipotesis, nilai t-statistik pada pengaruh komunikasi yang dibuat oleh perusahaan (firm-generated content) Banananina terhadap e-WOM pada brand Banananina di media sosial Instagram adalah sebesar 5,5231. Hal ini menunjukkan bahwa t hitung > t tabel atau 5,5231 > 1,64 sehingga hipotesis penelitian diterima. Hasil ini memberi arti bahwa adanya pengaruh positif yang signifikan pada komunikasi yang dibuat perusahaan (firm-generated content) Banananina terhadap e-WOM pada brand Banananina di media sosial Instagram dengan pengaruh sebesar 0,4812 sehingga semakin meningkat komunikasi yang dibuat perusahaan (firm-generated content) Banananina mengenai brand Banananina maka akan meningkatkan e-WOM brand Banananina di media sosial Instagram juga.

Hasil penelitian ini juga mendukung penelitian yang telah dilakukan oleh (Poturak \& Softic, 2019) yang menunjukkan bahwa firm-generated content ditemukan memiliki pengaruh positif yang signifikan terhadap e-WOM pada produk domestik tertentu. Jika dilihat dari analisis deskriptif pada variabel penelitian, variabel firmgenerated content termasuk dalam kategori agak tinggi dan tinggi. Setiap pernyataan pada variabel dari firm-generated content memiliki mayoritas jawaban setuju dan sangat setuju sehingga hal tersebut menunjukkan bahwa komunikasi yang dibuat oleh perusahaan atau e-commerce Banananina memperkuat e-WOM brand Banananina di media sosial Instagram. Hal ini diperkuat dengan hasil penelitian yang dilakukan, yaitu $\mathrm{t}$ hitung > t tabel atau 5,5231>1,64 yang menunjukkan adanya pengaruh yang signifikan.

Firm-generated content merupakan informasi yang dibuat oleh perusahaan untuk memberikan konten sebagai komunikasi yang positif membentuk citra positif brand mereka terhadap calon konsumen dan konsumen. FGC dalam penelitian ini adalah konten di media sosial Instagram yang dibuat oleh brand Banananina berupa 
pembagian foto, repost, hashtag, story, informasi produk, dan berbagai bentuk lainnya yang di posting melalui Instagram mereka. Seperti yang (Kumar, Bezawada, Rishika, Janakiraman, \& Kannan, 2016) pelajari bahwa firm-generated content merupakan pesan yang ditampilkan oleh halaman media sosial mereka bisa membantu perusahaan menggali hubungan satu persatu dengan pelanggan mereka melalui interaksi media sosial. Konten-konten yang diberikan Banananina tersebut dapat membentuk e-WOM sehingga dapat memengaruhi persepsi konsumen terhadap produk. Firm-generated content dalam penelitian ini mendapatkan hasil yang signifikan yang didominasi oleh jawaban setuju dan sangat setuju sehingga perusahaan Banananina menjadi penting dalam memberikan pengaruh terbentuknya e-WOM. Pada penelitian ini komponen kepuasan, ekspektasi, dan daya tarik responden terhadap konten yang dibuat oleh brand Banananina di Instagram termasuk dalam kategori tinggi. Sementara itu, pada komponen kinerja atau performance Banananina dalam menghasilkan konten di Instagram dibandingkan dengan brand lain memiliki kategori agak tinggi. Hasil penelitian uji hipotesis menunjukkan bahwa komunikasi yang dibuat oleh perusahaan Banananina di Instagram memiliki pengaruh yang signifikan terhadap penyebaran eWOM.

3. Terdapat Pengaruh yang Signifikan antara e-WOM terhadap Purchase Intention

Hipotesis 3 menyatakan bahwa terdapat pengaruh positif antara e-WOM dengan purchase intention konsumen pada brand Banananina di media sosial Instagram.

Berdasarkan hasil pengujian hipotesis, nilai t-statistik pada pengaruh e-WOM terhadap purchase intention konsumen pada brand Banananina di media sosial Instagram adalah sebesar 3,7373. Hal ini menunjukkan bahwa $t$ hitung $>t$ tabel atau $3,7373>1,64$ sehingga hipotesis penelitian diterima. Hasil ini memberi arti bahwa adanya pengaruh positif yang signifikan pada -WOM terhadap purchase intention konsumen pada brand Banananina di media sosial Instagram dengan pengaruh sebesar 0,2784 sehingga semakin meningkat e-WOM di media sosial Instagram maka akan meningkatkan minat beli (purchase intention) konsumen pada brand Banananina.

Hasil penelitian ini juga mendukung penelitian yang telah dilakukan oleh (Poturak \& Softic, 2019) yang menunjukkan bahwa e-WOM ditemukan memiliki pengaruh positif yang signifikan terhadap minat beli pada sebuah brand. Jika dilihat dari analisis deskriptif pada variabel penelitian. Variabel e-WOM termasuk dalam kategori agak tinggi dan tinggi, setiap pernyataan pada variabel dari e-WOM memiliki mayoritas jawaban setuju dan sangat setuju sehingga hal tersebut menunjukkan bahwa komunikasi yang dibuat oleh perusahaan atau e-commerce Banananina memperkuat minat beli brand Banananina di media sosial Instagram. Hal ini diperkuat dengan hasil penelitian yang dilakukan, yaitu $\mathrm{t}$ hitung > t tabel atau 3,7373>1,64 yang menunjukkan adanya pengaruh yang signifikan.

Rekomendasi yang berasal dari teman dan kenalan dikenal sebagai Word-ofmouth yang menggambarkan bagian penting dari pemasaran sekarang. Informasi yang diterima orang-orang berasal dari teman yang membicarakan tentang produk atau jasa yang seringkali lebih efektif daripada informasi yang berasal dari media. Orang-orang 
lebih memiliki kepercayaan diri dari apa yang teman-teman mereka rekomendasikan daripada informasi yang diperoleh dari saluran media promosi (Talpau, 2014). EWOM memiliki definisi sebagai pertukaran informasi mengenai suatu produk, layanan, merek atau perusahaan yang berada di internet, dan komunikasi ini berperan penting terhadap keputusan pembelian konsumen karena bisa memengaruhi sikap konsumen dalam melakukan pembelian (Ismagilova, Dwivedi, Slade, \& Williams, 2017).

Komunikasi WOM diakui sebagai sumber informasi non-komersial dan terpercaya yang memiliki efek besar pada sikap konsumen dan perilaku pembelian (Kala \& Chaubey, 2018). Penelitian yang dilakukan oleh (Jalilvand \& Samiei, 2012) meneliti bahwa terdapat hubungan e-WOM dengan purchase intention, mereka menemukan bahwa e-WOM memiliki efek kuat secara langsung pada minat beli konsumen. Selain itu juga penelitian yang dilakukan oleh (Kala \& Chaubey, 2018) mengatakan bahwa e-WOM secara positif memainkan peran penting dalam meningkatkan minat beli pelanggan dan mengurangi pengeluaran promosi. Dengan menggunakan e-WOM, pelanggan akan mendapatkan lebih banyak interaksi dengan konsumen lain dan lebih cepat mendapatkan respon mengenai informasi produk. Ketika informasi produk atau jasa kurang jelas, konsumen cenderung mencari informasi lebih dan referensi dari sumber lain yang terpisah dari informasi produk dari sumber yang resmi (Sa'ait, Kanyan, \& Nazrin, 2016).

Pemasar dapat mengembangkan cara komunikasi yang pantas untuk membuat konsumen lebih tahu mengenai karakteristik brand tertentu dan dapat mengubah beberapa hal-hal negatif yang konsumen tahu mengenai brand atau produk melalui WOM secara online. E-WOM yang positif memerankan peran penting untuk meningkatkan minat beli konsumen, menciptakan gambaran yang disukai perusahaan dan brand mereka serta mengurangi biaya promosi (Jalilvand \& Samiei, 2012).

E-WOM pada penelitian ini mendapatkan hasil yang signifikan dengan dominasi jawaban responden setuju, sangat setuju, dan sangat setuju sekali sehingga e-WOM menjadi komponen yang penting dalam keputusan pembelian produk Banananina. Pada penelitian ini, responden sering melihat mengenai brand Banananina di Instagram mengenai konten mengenai Banananina melalui konsumen lain, hal ini ditunjukkan dengan tanggapan responden yang menjawab dengan rata-rata agak tinggi dan tinggi mengenai pendapatnya mengenai persebaran e-WOM terhadap minat beli. Pada hasilnya adalah bahwa persebaran e-WOM yang muncul mengenai brand Banananina memiliki pengaruh yang signifikan terhadap minat beli konsumen.

4. Terdapat Pengaruh yang Signifikan antara e-WOM terhadap Brand Equity

Hipotesis 4 menyatakan bahwa terdapat pengaruh positif antara e-WOM dengan brand equity pada brand Banananina di media sosial Instagram.

Berdasarkan hasil pengujian hipotesis, nilai t-statistik pada pengaruh e-WOM terhadap brand equity pada brand Banananina di media sosial Instagram adalah sebesar 18,6868. Hal ini menunjukkan bahwa t hitung > t tabel atau 18,6868 > 1,64 sehingga hipotesis penelitian diterima. Hasil ini memberi arti bahwa adanya pengaruh 
positif yang signifikan pada e-WOM terhadap brand equity pada brand Banananina di media sosial Instagram dengan pengaruh sebesar 0,7169 sehingga semakin meningkat e-WOM mengenai brand Banananina maka akan meningkatkan brand equity pada brand Banananina di media sosial Instagram.

Hasil penelitian ini juga mendukung penelitian yang telah dilakukan oleh (Poturak \& Softic, 2019) yang menunjukkan bahwa e-WOM ditemukan memiliki pengaruh positif yang signifikan terhadap brand equity pada sebuah brand. Jika dilihat dari analisis deskriptif pada variabel penelitian, variabel e-WOM termasuk dalam kategori agak tinggi dan tinggi. Setiap pernyataan pada variabel dari e-WOM memiliki mayoritas jawaban setuju dan sangat setuju sehingga hal tersebut menunjukkan bahwa komunikasi yang dibuat oleh perusahaan atau e-commerce Banananina berkaitan dengan brand equity dari brand Banananina di media sosial Instagram. Hal ini diperkuat dengan hasil penelitian yang dilakukan, yaitu t hitung $>t$ tabel atau 18,6868 $>$ 1,64 yang menunjukkan adanya pengaruh yang signifikan.

Penelitian yang dilakukan oleh (Syahrivar \& Ichlas, 2018) menemukan bahwa e-WOM berpengaruh terhadap seluruh dimensi dari brand equity. (Rimbano \& Putri, 2016) mengungkapkan bahwa ketika electronic word-of-mouth positif banyak dibuat maka akan memberikan keuntungan bagi perusahaan karena akan menguatkan suatu merek atau sebaliknya. (Severi, Ling, \& Nasermoadeli, 2014) juga melihat bahwa brand equity tidak lagi dinilai dengan sejumlah besar uang yang perusahaan investasikan, melainkan pelanggan yang memberikan nilai brand equity melalui apa yang mereka katakan satu sama lain.

E-WOM pada penelitian ini mendapatkan hasil yang signifikan dengan dominasi jawaban responden setuju, sangat setuju, dan sangat setuju sekali sehingga e-WOM menjadi komponen yang penting dalam membentuk brand equity pada brand Banananina. Pada penelitian ini, responden menjawab dengan rata-rata agak tinggi dan tinggi mengenai pendapatnya mengenai persebaran e-WOM. Pada hasilnya uji pengaruh adalah bahwa persebaran e-WOM yang muncul mengenai brand Banananina memiliki pengaruh yang signifikan terhadap brand equity.

5. Terdapat Pengaruh yang Signifikan antara Brand Equity terhadap Purchase Intention

Hipotesis 5 menyatakan bahwa terdapat pengaruh positif antara brand equity dengan purchase intention pada brand Banananina di media sosial Instagram.

Berdasarkan hasil pengujian hipotesis, nilai t-statistik pada pengaruh brand equity terhadap purchase intention pada produk dari brand Banananina di media sosial Instagram adalah sebesar 8,7182. Hal ini menunjukkan bahwa $t$ hitung $>\mathrm{t}$ tabel atau $8,7182>1,64$ sehingga hipotesis penelitian diterima. Hasil ini memberi arti bahwa adanya pengaruh positif yang signifikan pada brand equity terhadap purchase intention pada produk dari brand Banananina di media sosial Instagram dengan pengaruh sebesar 0,5939 sehingga semakin meningkat brand equity maka akan semakin meningkatkan purchase intention pada produk pada brand Banananina di media sosial Instagram. 
Penelitian (Harsa \& Syahputra, 2015), menemukan bahwa brand equity mempunyai efek yang signifikan terhadap minat beli. Semakin kuat brand equity pada produk maka semakin kuat rasa percaya diri konsumen kepada produk. Rasa percaya diri pada produk tersebut menimbulkan rasa ingin membeli oleh calon pembeli dan mengonsumsi produk sehingga perusahaan mendapatkan keuntungan. Adanya brand equity yang kuat pada sebuah brand akan membuat perusahaan tetap mampu untuk bersaing di pasar seiring dengan meningkatnya persaingan pasar.

Brand equity memiliki dampak positif terhadap minat beli pelanggan terutama pada faktor brand loyalty, brand awareness, brand association, dan perceived quality yang dapat menciptakan brand equity (Aaker, 1991). Menurut (Senthilnathan, 2012) pada penelitiannya, terdapat hubungan positif antara brand equity dengan minat beli. Menciptakan brand equity yang kuat untuk produk tertentu seringkali membuat merek tersebut memiliki pasar yang kuat, karena industri retail lebih kompetitif dengan banyak bisnis dengan mencari pelanggan, penting bahwa bisnis menggunakan strategi pasar untuk menciptakan brand equity.

6. Terdapat Pengaruh yang Signifikan antara e-WOM terhadap Purchase Intention melalui Brand Equity

Hipotesis 6 menyatakan bahwa terdapat pengaruh positif antara e-WOM dengan purchase intention konsumen melalui brand equity sebagai variabel intervening pada brand Banananina di media sosial Instagram.

Berdasarkan hasil pengujian hipotesis, nilai t-statistik pada pengaruh e-WOM terhadap purchase intention konsumen melalui brand equity sebagai variabel intervening pada brand Banananina di media sosial Instagram adalah sebesar 8,7182. Hal ini menunjukkan bahwa $t$ hitung $>\mathrm{t}$ tabel atau 6,5639 > 1,64 sehingga hipotesis penelitian diterima. Hasil ini memberikan arti bahwa brand equity dapat memediasi atau dapat menjadi variabel intervening dalam pengaruh e-WOM di media sosial Instagram terhadap minat beli (purchase intention) brand Banananina dengan pengaruh tidak langsung sebesar 0,4258 sehingga pengaruh total atau total effect eWOM di media sosial Instagram terhadap minat beli produk pada brand Banananina adalah sebesar 0,7041 yang merupakan jumlah dari pengaruh secara langsung dan tidak langsung yaitu $0,2784+0,4258=0,7041$.

Penelitian sebelumnya (Poturak \& Softic, 2019) menunjukkan bahwa terdapat pengaruh positif yang signifikan antara e-WOM dan brand equity pada hubungan minat beli dibandingkan hubungan e-WOM dengan minat beli itu sendiri. Hal ini menunjukkan bahwa hubungan antara e-WOM dan minat beli secara penuh dimediasi oleh brand equity. Pada penelitian ini juga menemukan hasil yang sama bahwa pengaruh secara tidak langsung lebih besar efeknya dibandingkan tanpa mediasi. Pengaruh melalui efek mediasi brand equity antara e-WOM dan purchase intention memiliki pengaruh signifikan yang lebih besar dibandingkan efek secara langsung eWOM dengan purchase intention.

Menurut (Poturak \& Softic, 2019), apabila diterjemahkan ke dalam bahasa pemasaran, hal ini menunjukkan bahwa adanya like, share, comment, post di media 
sosial secara signifikan berpengaruh pada persebaran informasi mengenai merek tertentu, menciptakan e-WOM. Rekomendasi secara online dan ide dari pelanggan lain sangat memberikan pengaruh keputusan dari konsumen, namun hal ini dipengaruhi oleh adanya brand association/brand awareness, perceived quality, dan brand loyalty. Fokus tentang bagaimana perusahaan berhubungan dengan konsumen secara online, menciptakan pengalaman yang positif atau negatif sehingga memengaruhi brand equity mereka. Merek yang memiliki brand equity yang tinggi cenderung lebih menguntungkan di pasar. Hal ini sesuai dengan penelitian yang telah dilakukan bahwa adanya efek mediasi dari brand equity meningkatkan minat beli lebih besar dibandingkan tanpa efek.

\section{Kesimpulan}

Penelitian ini membahas pengaruh komunikasi media sosial baik yang dibuat oleh pengguna Instagram maupun perusahaan Banananina yang membentuk e-WOM terhadap minat beli dan brand equity. Berdasarkan hasil pembahasan ditemukan bahwa usergenerated content memiliki pengaruh positif yang signifikan terhadap e-WOM, begitu pula dengan firm-generated content yang memiliki pengaruh signifikan terhadap e-WOM pada brand Banananina di media sosial Instagram. Kemudian e-WOM memiliki pengaruh positif yang signifikan terhadap purchase intention dan e-WOM juga memiliki pengaruh positif signifikan terhadap brand equity pada brand Banananina di media sosial Instagram.

Sedangkan untuk e-WOM yang dimediasi oleh brand equity sebagai variabel intervening, memiliki pengaruh positif secara signifikan terhadap purchase intention konsumen pada brand Banananina di media sosial Instagram. Nilai pengaruh e-WOM terhadap purchase intention secara langsung lebih kecil besarnya dibandingkan dengan nilai pengaruh menggunakan mediasi brand equity. Hal ini menunjukkan bahwa adanya mediasi variabel brand equity lebih memengaruhi minat beli konsumen lebih besar pada brand Banananina dibandingkan tanpa adanya mediasi. 
Analisis Pengaruh Komunikasi E-WOM terhadap Brand Equity dan Purchase Intention pada Luxury Fashion Brand Banananina di Media Sosial Instagram

\section{BIBLIOGRAFI}

Aaker, David A. (1991). Managing Brand Equity New York. Free Press: New York. Google Scholar

Abumalloh, R. A., Ibrahim, O. B., Nilashi, M., \& Abu-Ulbeh, W. (2017). A literature review on purchase intention factors in e-commerce. Asia International Multidisciplinary Conference, Universiti Teknologi Malaysia (UTM) or University of Technology, Malaysia (UTM). Google Scholar

Harsa, Rangkas Salsabila, \& Syahputra, Syahputra. (2015). Pengaruh Brand Equity Game Mario Terhadap Minat Beli Konsumen Nintendo Indonesia Pada Konsol Nintendo (studi Pada Komunitas Nintendo Indonesia). EProceedings of Management, 2(2). 112. Google Scholar

Haryono, Siswoyo. (2017). Metode SEM untuk Penelitian Manajemen AMOS Lisrel PLS. Jakarta: Luxima Metro Media. Google Scholar

Hermawan, Asep, \& Yusran, Husna Leila. (2017). Penelitian Bisnis Pendekatan Kuantitatif. Kencana. Google Scholar

Ismagilova, Elvira, Dwivedi, Yogesh K., Slade, Emma, \& Williams, Michael D. (2017). Electronic word of mouth (eWOM) in the marketing context: A state of the art analysis and future directions. SpringerBriefs in Business. UK: Amazon.co.uk: Kindle Store Google Scholar

Jalilvand, Mohammad Reza, \& Samiei, Neda. (2012). The effect of electronic word of mouth on brand image and purchase intention: An empirical study in the automobile industry in Iran. Iran: Marketing Intelligence \& Planning. Google Scholar

Jha, Bidyanand. (2019). The role of social media communication: Empirical study of online purchase intention of financial products. Global Business Review, 20(6), 1445-1461. Google Scholar

Kala, Devkant, \& Chaubey, D. S. (2018). The effect of eWOM communication on brand image and purchase intention towards lifestyle products in India. International Journal of Services, Economics and Management, 9(2), 143-157. Google Scholar

Kotler, Philip, \& Armstrong, Gary. (2012). Principles of marketing 14th edition. New Jearsey: Pearson Education Inc, 67. Google Scholar

Kotler, Philip, \& Keller, Kevin Lane. (2016). Marketing management (15th global ed.). England: Pearson. Google Scholar

Kumar, Ashish, Bezawada, Ram, Rishika, Rishika, Janakiraman, Ramkumar, \& Kannan, P. K. (2016). From social to sale: The effects of firm-generated content in social media on customer behavior. Journal of Marketing, 80(1), 7-25. Google Scholar 
Nancy, Y. (2019). Pengguna Facebook \& Instagram di Indonesia Terbanyak ke 4 di Dunia. Retrieved from https://tirto.id/pengguna-facebook-instagram-di-indonesiaterbanyak-ke-4-di-dunia-ee8n. Google Scholar

POTURAK, Mersid, \& SOFTIC, Sumeja. (2019). Influence of social media content on consumer purchase intention: Mediation effect of brand equity. Eurasian Journal of Business and Economics, 12(23), 17-43. Google Scholar

Pusparisa, Y. (2019). 5 Jenis Barang yang Paling Diburu Konsumen di E-Commerce. Retrieved from https://databoks.katadata.co.id/datapublish/2019/11/11/5-sektorbarang-yang-paling-diburu-konsumen. Google Scholar

Rimbano, Dheo, \& Putri, Meilya Sari Eka. (2016). Pengaruh Kecerdasan Emosional, Kecerdasan Spiritual, dan Perilaku Belajar Terhadap Tingkat Pemahaman Akuntansi. Orasi Bisnis: Jurnal Ilmiah Administrasi Niaga, 15(1). 1-15. Google Scholar

Sa'ait, Noraini, Kanyan, Agnes, \& Nazrin, Mohammad Fitri. (2016). The effect of eWOM on customer purchase intention. International Academic Research Journal of Social Science, 2(1), 73-80. Google Scholar

Sagala, Oktaviani Br, \& Rachmawati, E. (2016). Instagram content towards customers' purchase intention for start-up culinary company. Advanced in Economics, Business and Management Research, 15, 371-376. Google Scholar

Schivinski, Bruno, \& Dabrowski, Dariusz. (2015). The impact of brand communication on brand equity through Facebook. Journal of Research in Interactive Marketing. Google Scholar

Senthilnathan, Samithamby. (2012). The relationship of brand equity to purchase intention. IUP Journal of Marketing Management, May. Google Scholar

Severi, Erfan, Ling, Kwek Choon, \& Nasermoadeli, Amir. (2014). The impacts of electronic word of mouth on brand equity in the context of social media. International Journal of Business and Management, 9(8), 84-96. Google Scholar

Soewandi, Melinda. (2015). The impact of social media communication forms on brand equity dimensions and consumer purchase intention. IBuss Management, 3(2). 204213. Google Scholar

Syahrivar, Jhanghiz, \& Ichlas, Andy Muhammad. (2018). The Impact of Electronic Word of Mouth (E-WoM) on Brand Equity of Imported Shoes: Does a Good Online Brand Equity Result in High Customers' Involvements in Purchasing Decisions? The Asian Journal of Technology Management, 11(1), 57-69. Google Scholar

Talpau, Alexandra. (2014). Social media-A new way of communication. Bulletin of the Transilvania University of Brasov. Economic Sciences. Series V, 7(2), 45. Google Scholar 
Analisis Pengaruh Komunikasi E-WOM terhadap Brand Equity dan Purchase Intention pada Luxury Fashion Brand Banananina di Media Sosial Instagram

Zailskaite-Jakste, Ligita, \& Kuvykaitè, Rita. (2013). Communication in social media for brand equity building. Economics and Management, 18(1), 142-153. Google Scholar

Zarella, D. (2010). The Social Media Marketing Book. Sebastopol. Kanada: O'reilly. Google Scholar

\section{Copyright holder:}

Hanako Fatimah Pertiwi, Effy Zalfiana Rusfian (2021)

First publication right:

Syntax Literate: Jurnal Ilmiah Indonesia

This article is licensed under:

(c) (i) (O) 